\title{
Adapting wheat ideotypes for climate change: accounting for uncertainties in CMIP5 climate projections
}

\author{
Mikhail A. Semenov*, Pierre Stratonovitch \\ Computational and Systems Biology Department, Rothamsted Research, Harpenden, Hertfordshire AL5 2JQ, UK
}

\begin{abstract}
This study describes integration of climate change projections from the Coupled Model Intercomparison Project Phase 5 (CMIP5) multi-model ensemble with the LARS-WG weather generator, which delivers an attractive option for the downscaling of large-scale climate projections from global climate models (GCMs) to local-scale climate scenarios for impact assessments. A subset of 18 GCMs from the CMIP5 ensemble and 2 Representative Concentration Pathways (RCPs), RCP4.5 and RCP8.5, were integrated with LARS-WG. For computationally demanding impact assessments, where it is not practical to explore all possible combinations of GCM $\times \mathrm{RCP}$, a climate sensitivity index could be used to select a subset of GCMs which preserves the range of uncertainty found in CMIP5. This would allow us to quantify uncertainty in predictions of impacts resulting from the CMIP5 ensemble by conducting fewer simulation experiments. In a case study, we describe the use of the Sirius wheat simulation model to design in silico wheat ideotypes that are optimised for future climates in Europe, sampling uncertainty in GCMs, emission scenarios, time periods and European locations with contrasting climates. Two contrasting GCMs were selected for the analysis, 'hot' HadGEM2-ES and 'cool' GISS-E2-R-CC. Despite large uncertainty in future climate projections, we were able to identify target traits for wheat improvement which may assist breeding for high-yielding wheat cultivars with increased yield stability.
\end{abstract}

KEY WORDS: Sirius wheat model $\cdot$ LARS-WG weather generator $\cdot$ Downscaling $\cdot$ CMIP5 ensemble $\cdot$ Impact assessment

Resale or republication not permitted without written consent of the publisher

\section{INTRODUCTION}

The Intergovernmental Panel on Climate Change (IPCC) Fifth Assessment Report (AR5) (Stocker et al. 2013, Barros et al. 2014, Edenhofer et al. 2014) is based on large datasets of climate projections developed by the Coupled Model Intercomparison Project Phase 5 (CMIP5) (Taylor et al. 2012) and coordinated by the World Climate Research Programme. Twentyfive modelling groups worldwide performed a large set of coordinated climate simulations in which over 50 variants of global climate models (GCMs) were run for a common set of experiments, sampling uncertainties in emission scenarios, model structures and initial conditions. Compared with CMIP3, CMIP5 used a much larger ensemble of more complex climate models with higher spatial resolution, better description of climate forcing, more detailed representation of feedbacks associated with carbon cycles and with clouds, more types of emission scenario and more climatic variables and diagnostics stored for later use. The CMIP5 simulations are driven by a new set of emission scenarios consistent with new Representative Concentration Pathways (RCPs) (Moss et al. 2010). These are different from the emission scenarios described in the IPCC Special Report on Emissions Scenarios (SRES), which included no policy intervention and were used in the earlier IPCC Fourth Assessment Report (AR4) (Nakicenovic \& Swart 2000, Parry et al. 2007, Solomon et al. 2007). The RCPs include 
mitigation measures to achieve specific emission targets. The 4 RCPs formulated are based on a range of projections of future population growth, technological development and societal responses: RCP8.5 (rising), RCP6.0 (stabilisation without overshoot), RCP4.5 (stabilisation without overshoot) and RCP2.6 (peak and decline) (Moss et al. 2010). The labels, e.g. RCP8.5, provide estimations of the radiative forcing, e.g. $8.5 \mathrm{~W} \mathrm{~m}^{-2}$, by 2100 relative to preindustrial conditions. All RCPs should be considered as plausible, and do not have probabilities attached to them. It was required from all GCMs to provide climate projections for long-term experiments up to 2100 and beyond for RCP4.5 and RCP8.5.

Although a direct comparison between SRES and RCP emission scenarios could be problematic, Knutti \& Sedlacek (2013) proposed a consistent probabilistic framework for such comparison, which takes into account uncertainty in climate sensitivity. The authors used the reduced-complexity carbon-cycle and climate model MAGICC (Meinshausen et al. 2011) to compare climate scenarios based on the SRES and RCPs. They found that the median of global temperature increase by 2100 predicted for the SRES B1 scenario is similar to the prediction for RCP4.5, although temperatures in RCP4.5 rises faster than in SRES B1 until mid-century, and more slowly afterwards. The predicted global temperature increase for the SRES A1FI scenario of $4.7^{\circ} \mathrm{C}$ by 2100 is close to the predicted RCP8.5 increase of $4.6^{\circ} \mathrm{C}$, while temperatures in RCP8.5 rise more slowly than in SRES A1FI during the period between 2035 and 2080 and faster during other periods (Knutti \& Sedlacek 2013).

Impact studies and risk assessments provide the scientific basis to explore adaptation options to a changing climate (Barros et al. 2014). Models used in impact assessments of climate change are typically process-based, e.g. models of crop growth, flood risk or invasive species, and require climate information on a local scale with high temporal and spatial resolutions (Wilby et al. 2009). Using the output from GCMs directly with process-based impact models is challenging, because of coarse spatial resolution of GCMs and the existence of biases in model outputs (Wang et al. 2014). There are several approaches to downscaling GCM climate projections to local-scale climate scenarios, ranging from dynamical downscaling with nested regional climate models to the application of various statistical techniques, each of which has its own advantages and disadvantages (Wilby et al. 2009). Downscaling with a stochastic weather generator (WG) (Wilks 1992, Semenov \& Barrow 1997) has been used extensively in impact assess- ments, because WGs deliver climate scenarios that match the statistical properties of observed weather. WGs are computationally inexpensive, provide daily or even hourly meteorological variables preserving statistical interrelationships between variables, and allow generation of arbitrarily long weather series (Wilks 2012). This is particularly important for evaluating the statistics of extreme events (Kysely et al. 2013, Semenov et al. 2014).

The objective of this paper is to describe integration of climate projections from the CMIP5 ensemble with the LARS-WG weather generator (Semenov \& Stratonovitch 2010, Calanca \& Semenov 2013). For computer-intensive impact assessment studies where exploration of potential impacts for each GCM requires substantial resources and computing time, we propose to use climate sensitivity indices (CSIs) in order to limit the number of GCMs used to construct local-scale scenarios. By selecting a small number of GCMs from the ensemble with high and low climate sensitivity over a region of interest, we would be able to preserve the diversity in climate projections representative of the whole CMIP5 ensemble. This should allow us to quantify uncertainty in predictions from impact models underpinning better-informed decision making. In our case study, we describe the use of the Sirius wheat simulation model (Jamieson et al. 1998, Jamieson \& Semenov 2000, Lawless et al. 2005, Semenov et al. 2014) to design in silico wheat ideotypes that are optimised for future climates in Europe, sampling uncertainty in GCMs, emission scenarios, time periods and European locations with contrasting climates. Despite large uncertainty in future climate projections, we were able to identify target traits for wheat improvement which may assist breeding for high-yielding wheat cultivars with increased yield stability.

\section{INTEGRATION OF CMIP5 CLIMATE PROJECTIONS WITH LARS-WG}

LARS-WG is a stochastic weather generator that has been widely used in numerous studies on impact assessment of climate change for nearly 2 decades (Racsko et al. 1991, Semenov \& Barrow 1997). The latest examples include studies by Agarwal et al. (2014), Hassan et al. (2014), Luo et al. (2014), Persson \& Hoglind (2014), Semenov et al. (2014), Storkey et al. (2014) and Vanuytrecht et al. (2014). Recently, its application has been facilitated by integrating a dataset of site parameters for the baseline 1980-2010 European climates (Semenov et al. 2010, 2013) and 
integration scenarios based on the CMIP3 ensemble of GCMs (Semenov \& Stratonovitch 2010) and the EU-ENSEMBLE ensemble of regional climate models over Europe (Calanca \& Semenov 2013). This has created a unique repository of climate scenarios, ELPIS (Semenov et al. 2010), that can be accessed directly within the LARS-WG interface. A logical step is the integration of the latest CMIP5 multimodel ensemble (Taylor et al. 2012), which was used in the latest IPCC AR5 (Stocker et al. 2013, Edenhofer et al. 2014).

\subsection{Local-scale scenarios based on WG}

We describe briefly the use of WG in construction of future climate scenarios. Let us consider $O_{t}^{s}$ to be an observed daily time series of a suite of climatic variables at a site $s$ for a period $t$ of several years e.g. 1980-2010 is currently used to represent the baseline climate in impact assessment studies. Using observed data, WG estimates a set of parameters of distributions of climate variables $p_{t}^{s}$ at a site $s$ for a period $t$ :

$$
\mathrm{WG}: O_{t}^{s} \rightarrow p_{t}^{s}
$$

Some WGs use parametric distributions to approximate distributions of climatic variables with relatively few parameters to estimate (Richardson 1981, Racsko et al. 1991, Wilks 1992). Other WGs use semi-empirical distributions, where observed distributions are approximated by empirical cumulative probability functions (Qian et al. 2004, Semenov 2008, Semenov et al. 2010). Typically, 20-30 yr of observed daily weather are required to estimate site parameters accurately.

Site parameters $p_{t}^{s}$ are used by WG to generate synthetic daily time-series $Y_{t}^{s}$ for a site $s$ which could be considered as samples of typical weather for a period $t$ :

$$
\mathrm{WG}: p_{t}^{s} \rightarrow Y_{t}^{s}
$$

The number of generated years of synthetic daily weather $Y_{t}^{s}$ could be arbitrarily long and does not need to be equal to the number of years of observed weather that was used to estimate distribution parameters. For example, to analyse the impact of extreme weather events on crop yields, $300 \mathrm{yr}$ of daily weather were generated and used in conjunction with a crop simulation model (Semenov \& Shewry 2011). Individual years of generated weather should be considered as samples of weather typical at a site $s$ for a period $t$. Similarity between observed
$O_{t}^{s}$ and generated weather $Y_{t}^{s}$ could be tested by various statistical tests, such as the KolmogorovSmirnov test, a nonparametric test for the equality of 1-dimensional probability distributions, or $t$-test, a statistical test for the equality of the means of 2 samples (Semenov et al. 1998). Extreme statistics, such as return periods or return values, are also used to compare observed and generated weather, particularly in applications where accurate reproduction of extremes is important (Kysely \& Dubrovsky 2005, Qian et al. 2008).

GCMs, $M$, are used to predict evolution of climate in response to changes in climate forcing, e.g. $\mathrm{CO}_{2}$, aerosols, solar activity, volcanoes and so on. These physical models are run over a grid, $G=\{g\}$, with individual grid-cell size varying from 75 to $300 \mathrm{~km}$ (see Table 1). For a grid cell $g$ and a period $t$ (baseline or future), the climate model simulates time-series of climatic variables $M:\{g, t\} \rightarrow M_{t}^{g}$. Statistical properties of the climate model output $M_{t}^{g}$ could be very different from properties of observed weather $O_{t}^{s}$ at a site $s$ located inside a grid cell $g$. Despite extensive efforts to improve GCMs' performance in the simulation of various aspects of the climate system in the CMIP5 project, there are still substantial temperature biases and deficiencies in the GCMs' outputs (Knutti $\&$ Sedlacek 2013). One recent study shows that even the CMIP5 ensemble mean (averaged over 22 GCMs, which typically performs better than any individual GCM from the ensemble) of the annual mean sea surface temperature has biases up to $-3^{\circ} \mathrm{C}$ in the Northern Hemisphere and up to $+3^{\circ} \mathrm{C}$ in the Southern Hemisphere (Wang et al. 2014). These biases and errors in some regions can be linked with biases and errors at faraway locations, which implies that improving modelling of regional processes may not result in overall better model performance, because the effects of remote biases may outweigh them. Climate projections from GCMs need to be downscaled to local-scale climate scenarios. One of the commonly used downscaling techniques is based on WGs and climatic change factors derived from GCMs (Wilks 1992, Barrow \& Semenov 1995, Wilby et al. 1998, Semenov 2007).

Despite biases and errors in GCM outputs, we can assume that, by analysing climate projections for the baseline and future periods, we could derive changes in climate which would be free from bias. This is valid only under the assumption that GCM biases are invariant in time (Christensen et al. 2008). Change factors are defined as differences in climate statistics between future $t_{f}$ and baseline $t_{b s}$ periods for each grid cell $g$ : 


$$
\Delta_{t_{b s}, t_{f}}^{g}=M_{t_{f}}^{g}-M_{t_{b s}}^{g}
$$

For example, for temperatures, absolute changes in monthly mean temperatures are used as a change factor. For precipitation, relative changes in monthly mean total precipitation are more common. These change factors describe changes in mean climate. To describe changes in climatic variability, other climate statistics can be used, e.g. relative changes in monthly mean of the length of wet or dry spells, which affect changes in daily precipitation and daily temperature in a nonlinear way (Semenov 2007). On occasion, change factors could have unrealistically large differences either between neighbouring grid cells or between consecutive months for a single grid cell. Spatial and temporal kernel average smoothers (KAS) are, therefore, applied to obtain a more robust climate signal (Calanca \& Semenov 2013):

$$
\mathrm{KAS}: \Delta_{t_{b s}, t_{f}}^{g} \rightarrow \tilde{\Delta}_{t_{b s}, t_{f}}^{g}
$$

Change-factors $\tilde{\Delta}_{t_{b s}, t_{f}}^{s}$ are calculated for a grid cell $g$. Change factors for a specific site $s, \tilde{\Delta}_{t_{b s}, t_{f^{\prime}}}^{s}$ are estimated by using the change factors for neighbouring grids and applying inverse-distance weighting (IDW) interpolation (Calanca \& Semenov 2013):

$$
\text { IDW }: \tilde{\Delta}_{t_{b s}, t_{f}}^{g} \rightarrow \tilde{\Delta}_{t_{b s}, t_{f}}^{s}
$$

Using site parameters for the baseline $p_{t_{b s}}^{S}$ derived from observed daily weather and change factors $\tilde{\Delta}_{t_{b s}, t_{f}}^{s}$ describing changes in climate as predicted by GCM, we can compute site parameters $p_{t_{f}}^{s}$ for the future period $t_{f}$ :

$$
p_{t_{f}}^{s}=p_{t_{b s}}^{s}+\tilde{\Delta}_{t_{b s}, t_{f}}^{s}
$$

The adjustment of site parameters depends on specific parameterisations and assumptions of individual WGs (Wilby et al. 1998, Wilks 2012, Calanca \& Semenov 2013). This set of parameters $p_{t_{f}}^{s}$ is used by WG to generate local-scale daily climate scenarios for the future period $t_{f}$ :

$$
\mathrm{WG}: p_{t_{f}}^{S} \rightarrow Y_{t_{f}}^{s}
$$

All these steps have been incorporated in a new version 6.0 of the LARS-WG stochastic weather generator which integrates climate projections from the CMIP5 ensemble.

\subsection{Climate sensitivity of the CMIP5 ensemble}

A subset of 18 GCMs from the CMIP5 multi-model ensemble was incorporated into the LARS-WG weather generator (Table 1). Two RCPs were inte- grated, i.e. RCP8.5, which represents a rising radiative forcing pathway leading to $8.5 \mathrm{~W} \mathrm{~m}^{-2}$ in 2100 (Riahi et al. 2007), and RCP4.5, which represents a stabilisation without overshoot pathway leading to $4.5 \mathrm{~W} \mathrm{~m}^{-2}$ radiative forcing at stabilisation after 2100 (Smith \& Wigley 2006, Wise et al. 2009). Corresponding $\mathrm{CO}_{2}$ concentrations (ppm) for RCP4.5 and RCP8.5 are presented in Table 2.

The CMIP5 multi-model ensemble has more than twice as many models and many more experiments compared with the CMIP3 ensemble. It might not always be practical to use all climate models from the CMIP5 ensemble in a particular impact assessment study, as substantial resources and computer time are required for evaluation of each climate scenario. To assist with the selection of GCMs for a specific impact study in a region of interest, we computed a CSI for each GCM incorporated into LARS-WG for 21 regions as defined in Giorgi \& Francisco (2000) (our Table 3). CSI is defined as the spatial average (calculated over a region land-mask only) of differences between mean values for the future, 2080-2100, for RCP8.5 and mean values for the CMIP5 baseline, 1995-2005. CSI was computed for mean air temperature calculated as differences in temperatures $\left({ }^{\circ} \mathrm{C}\right)$, and for precipitation calculated as a relative change in precipitation total (\%). Fig. 1 presents CSIs for the Mediterranean Basin (MED) and Northern Europe (NEU) for 18 GCMs. All GCMs predicted an increase in annual precipitation in NEU (by up to $25 \%$ for MIROC-ESM), and a decrease in annual precipitation in MED (by up to $-36 \%$ for IPSL-CM5A-MR). Changes in mean annual temperature were similar for both regions, NEU and MED, and varied from $+3.1^{\circ} \mathrm{C}$ for INMCM4 to $+6.6^{\circ} \mathrm{C}$ for MIROC-ESM. Annual CSIs for 21 regions and 18 GCMs are presented as heat maps in Table 4 for temperature and in Table 5 for precipitation.

\section{ADAPTING WHEAT TO AN UNCERTAIN FUTURE}

As an illustration, we demonstrate how new CMIP5-based scenarios were used in designing wheat ideotypes optimised for future climate conditions in Europe (Donald 1968). Ideotype design is a computationally intensive problem, which requires several hours of computation on a powerful multiprocessor workstation for a single combination of Site $\times \mathrm{GCM} \times \mathrm{RCP} \times$ Period .

Increasing yield potential for major cereals is needed to meet the projected increased demand for 


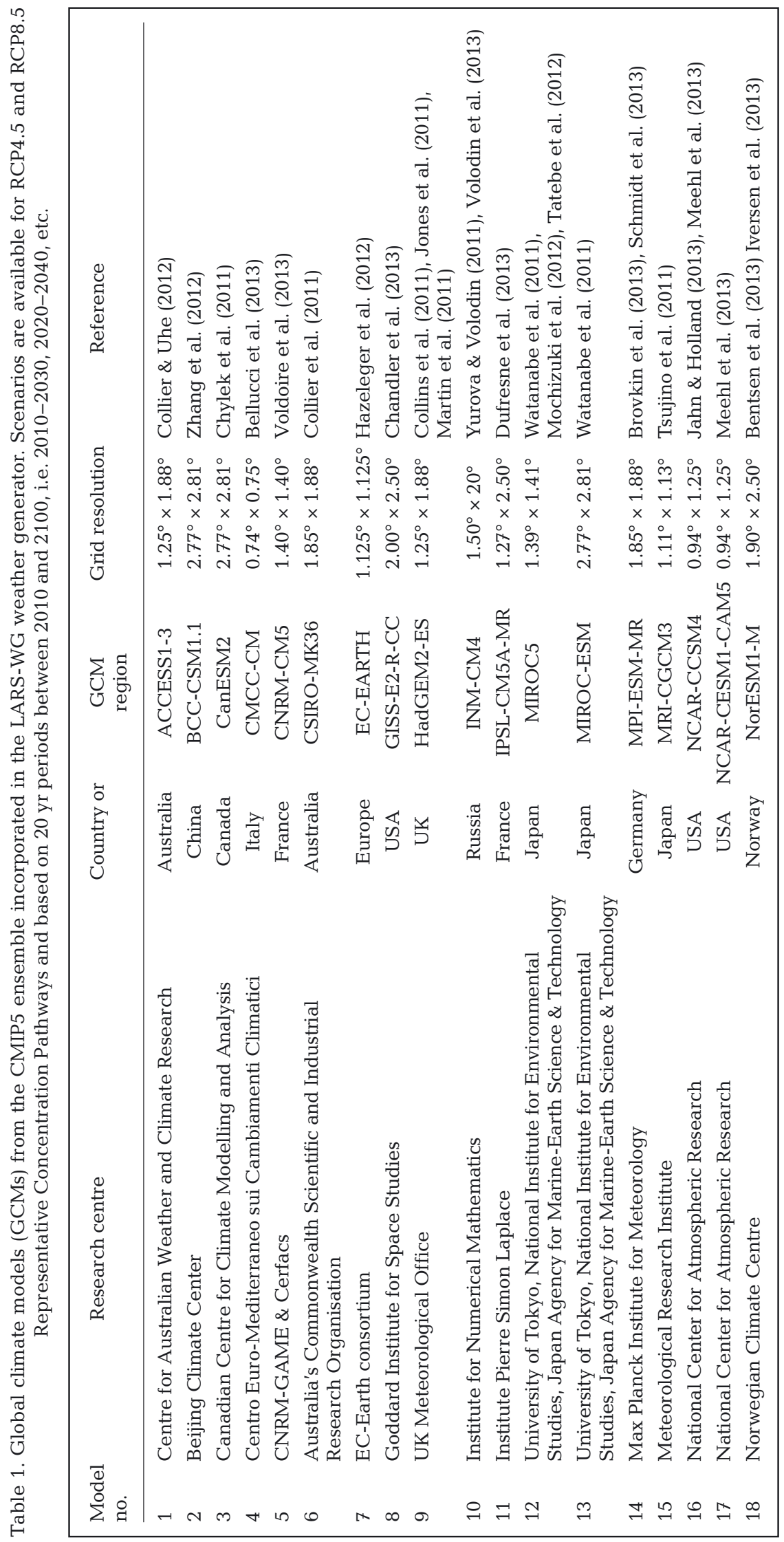

world food supply of about $70 \%$ by 2050 (FAO 2009). Europe is the largest producer of wheat, the third most widely grown cereal crop after maize and rice. Considering the limitations on expanding crop-growing areas in Europe, a significant increase in crop productivity will be needed (Parry et al. 2011). Wheat growth and development is highly sensitive to climatic and environmental variations (Porter \& Semenov 2005). Climate change is characterised by shifts in weather patterns, increases in climatic variability and extreme weather events (Fischer et al. 2013), and, therefore, represents a considerable challenge to achieving the $70 \%$ increase in target for world food production. New wheat cultivars with an optimal combination of traits for future climatic conditions will be required. However, the inherent uncertainty of climate predictions presents a challenge to breeders who have limited time and resources and must select the most appropriate traits for improvement (Semenov \& Halford 2009, Foulkes et al. 2011, Semenov \& Shewry 2011). Modelling provides a rational framework to design and test in silico new wheat ideotypes optimised for target environments and future climatic conditions (Hammer et al. 2006, Tardieu \& Tuberosa 2010, Semenov et al. 2014).

Here, we used Sirius, a crop simulation model, to design wheat ideotypes optimised for future climatic projections for 2 climate models with very different climate sensitivity, HadGEM 2-ES (number 9 in Fig. 1) and GISSE2-R-CC (number 8 in Fig. 1), and 2 RCPs, RCP4.5 and RCP8.5. This allowed us to optimise and compare wheat ideotypes for 4 contrasting future scenarios which represent the range of uncertainty within the CMIP5 ensemble. HadGEM2-ES projections for 2080-2100 are nearly the hottest and driest (during summer) projections for both northern (NEU) and southern (MED) Europe (Fig. 1). GISS-E2-R-CC projections are nearly the coolest pro- 
Table 2. $\mathrm{CO}_{2}$ concentrations (ppm) for RCP4.5 and RCP8.5 Representative Concentration Pathways (www.pik-potsdam.de/ mmalte/rcps/index.htm\#Download)

\begin{tabular}{|lcccccccccc|}
\hline & 2000 & 2010 & 2020 & 2030 & 2040 & 2050 & 2060 & 2070 & 2080 & 2090 \\
\hline RCP4.5 & 369 & 389 & 411 & 435 & 460 & 487 & 509 & 524 & 531 & 533 \\
RCP8.5 & 369 & 389 & 415 & 449 & 489 & 541 & 604 & 677 & 758 & 844 \\
\hline
\end{tabular}

Table 3. List of regions as defined in Giorgi \& Francisco (2000) for which climate sensitivity indexes were calculated

\begin{tabular}{|lcrr|}
\hline Name & Acronym & Latitude & Longitude \\
\hline Australia & AUS & $45^{\circ}-11^{\circ} \mathrm{S}$ & $110^{\circ}-155^{\circ} \mathrm{E}$ \\
Amazon Basin & AMZ & $20^{\circ} \mathrm{S}-12^{\circ} \mathrm{N}$ & $82^{\circ}-34^{\circ} \mathrm{W}$ \\
Southern South America & SSA & $56^{\circ}-20^{\circ} \mathrm{S}$ & $76^{\circ}-40^{\circ} \mathrm{W}$ \\
Central America & CAM & $10^{\circ}-30^{\circ} \mathrm{N}$ & $116^{\circ}-83^{\circ} \mathrm{W}$ \\
Western North America & WNA & $30^{\circ}-60^{\circ} \mathrm{N}$ & $130^{\circ}-103^{\circ} \mathrm{W}$ \\
Central North America & CNA & $30^{\circ}-50^{\circ} \mathrm{N}$ & $103^{\circ}-85^{\circ} \mathrm{W}$ \\
Eastern North America & ENA & $25^{\circ}-50^{\circ} \mathrm{N}$ & $85^{\circ}-60^{\circ} \mathrm{W}$ \\
Alaska & ALA & $60^{\circ}-72^{\circ} \mathrm{N}$ & $170^{\circ}-103^{\circ} \mathrm{W}$ \\
Greenland & GRL & $50^{\circ}-85^{\circ} \mathrm{N}$ & $103^{\circ}-10^{\circ} \mathrm{W}$ \\
Mediterranean Basin & MED & $30^{\circ}-48^{\circ} \mathrm{N}$ & $10^{\circ} \mathrm{W}-40^{\circ} \mathrm{E}$ \\
Northern Europe & NEU & $48^{\circ}-75^{\circ} \mathrm{N}$ & $10^{\circ} \mathrm{W}-40^{\circ} \mathrm{E}$ \\
Western Africa & WAF & $12^{\circ} \mathrm{S}-18^{\circ} \mathrm{N}$ & $20^{\circ} \mathrm{W}-22^{\circ} \mathrm{E}$ \\
Eastern Africa & EAF & $12^{\circ} \mathrm{S}-18^{\circ} \mathrm{N}$ & $22^{\circ}-52^{\circ} \mathrm{E}$ \\
Southern Africa & SAF & $35^{\circ}-12^{\circ} \mathrm{S}$ & $10^{\circ} \mathrm{W}-52^{\circ} \mathrm{E}$ \\
Sahara & SAH & $18^{\circ}-30^{\circ} \mathrm{N}$ & $20^{\circ} \mathrm{W}-65^{\circ} \mathrm{E}$ \\
Southeast Asia & SEA & $11^{\circ} \mathrm{S}-20^{\circ} \mathrm{N}$ & $95^{\circ}-155^{\circ} \mathrm{E}$ \\
East Asia & EAS & $20^{\circ}-50^{\circ} \mathrm{N}$ & $100^{\circ}-145^{\circ} \mathrm{E}$ \\
South Asia & SAS & $5^{\circ}-30^{\circ} \mathrm{N}$ & $65^{\circ}-100^{\circ} \mathrm{E}$ \\
Central Asia & CAS & $30^{\circ}-50^{\circ} \mathrm{N}$ & $40^{\circ}-75^{\circ} \mathrm{E}$ \\
Tibet & TIB & $30^{\circ}-50^{\circ} \mathrm{N}$ & $75^{\circ}-100^{\circ} \mathrm{E}$ \\
North Asia & NAS & $50^{\circ}-70^{\circ} \mathrm{N}$ & $40^{\circ}-180^{\circ} \mathrm{E}$ \\
\hline
\end{tabular}

Photosynthesis. We assume that a $10 \%$ increase in light conversion efficiency could be achieved in the future (Tambussi et al. 2007). In addition, in Sirius, radiation use efficiency (RUE) is proportional to $\left[\mathrm{CO}_{2}\right]$ with an increase of $30 \%$ for a doubling of $\left[\mathrm{CO}_{2}\right]$ compared with the baseline of $338 \mathrm{ppm}$, which is in agreement with the recent meta-analysis of field-scale experiments on the effects of $\left[\mathrm{CO}_{2}\right]$ on crops (Vanuytrecht et al. 2012).

Phenology. Three cultivar parameters are directly related to phenological development of wheat: phyllochron $P h$, daylength response $P p$ and duration of grain filling Gf (Table 7). Modifying the duration and timing of crop growth cycle in relation to seasonal variations of solar radiation and water availability may have significant effects on yield (Tambussi et al. 2007). An optimal flowering time has been the single most important factor in maximising yield in dry environments (Richards 1991). Increasing the duration of the grainfilling period Gf has been suggested as a possible trait for increasing yield potential in wheat (Evans \& Fischer 1999).

jections with changes in precipitation close to the CMIP5 ensemble average (Fig. 1). We selected 2 contrasting sites in Europe, Rothamsted, UK, and Seville, Spain (Table 6). A wheat ideotype is described by 9 cultivar parameters of Sirius considered most promising for improvement of yield potential under climate change (see Table 7). We used an evolutionary algorithm with self-adaptation to optimise these parameters for future climatic conditions (Stratonovitch \& Semenov 2010).

\subsection{Cultivar parameters for optimisation}

The detailed description of cultivar parameters selected for optimisation is given in Semenov (Semenov et al. 2014). The ranges of parameter values are presented in Table 7 . Here, we briefly describe these parameters.
Canopy. Two cultivar parameters to be optimised are related to canopy, i.e. maximum area of flag leaf layer $A$, and duration of leaf senescence $S$. By varying the maximum area of the flag leaf layer, we change the rate of canopy expansion and the maximum achievable leaf area index (LAI). This in turn will change the pattern of light interception and transpiration and, therefore, will affect crop growth and final grain yield. One of the strategies to increase grain yield is to maintain green leaf area longer after anthesis, the so-called 'stay-green' trait (Triboi \& Triboi-Blondel 2002).

Tolerance to drought. Both daily biomass production (photosynthesis) and leaf senescence depend on the drought stress factor SF calculated daily as the ratio of actual to potential evapotranspiration. Production of new daily biomass decreases proportionally to the drought biomass reduction factor Wsa. In Sirius, the rate of leaf senescence can be accelerated 


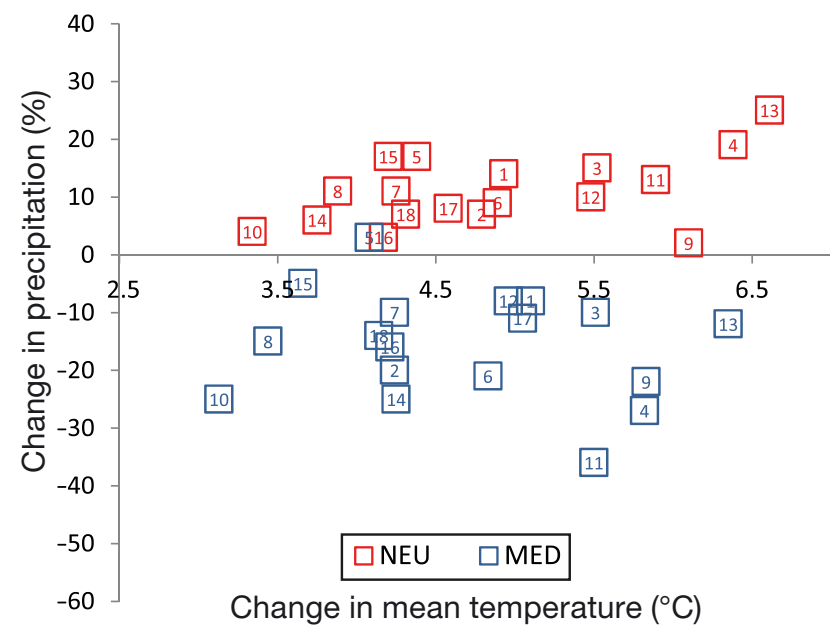

Fig. 1. Absolute changes in mean annual temperature and relative changes in annual mean precipitation calculated over Northern Europe (NEU, red) and Mediterranean Basin (MED, blue) regions for RCP8.5 between future 2080-2100 and global climate model (GCM) baseline 1995-2005 for 18 GCMs from the CMIP5 ensembles. Numbers inside the squares refer to model numbers shown in Table 1. Values are calculated for land grid-cells from a 1-degree land mask

by nitrogen shortage. water, or temperature stresses in order to sustain grain filling. Earlier leaf senescence will reduce grain yield. Increasing tolerance to drought stress (reducing Wss) will make leaves stay green longer under water stress and potentially increase grain yield.

Root water uptake. In Sirius, plants can extract up to $10 \%$ of available soil water from the top layer in any single day and only root water uptake $(R u)(\%)$ from the bottom layer at the maximum root depth. A faster water uptake reduces stress experienced by the plant and stimulates plant growth. However, in dry environments with a likely drought at the end of the growing season, a slower water uptake may achieve, on average, higher yields (Manschadi et al. 2006).

The latest version of Sirius incorporates responses to high temperature during flowering and seed sets (Stratonovitch \& Semenov in press). From the beginning of flowering, wheat cultivars could be sensitive to high temperature at 2 key development stages (Grant et al. 2011). First, during meiosis, temperatures exceeding $30^{\circ} \mathrm{C}$ are reported to cause abnormal development of both ovary and anthers, which reduces floret fertility and the number of developing grains (Wheeler et al. 1996, Ferris et al. 1998, Alghabari et al. 2014). Then, at the beginning of grain filling, temperatures above $35^{\circ} \mathrm{C}$ affect the development of the endosperm, which limits maximum grain size (Hawker \& Jenner 1993). To account

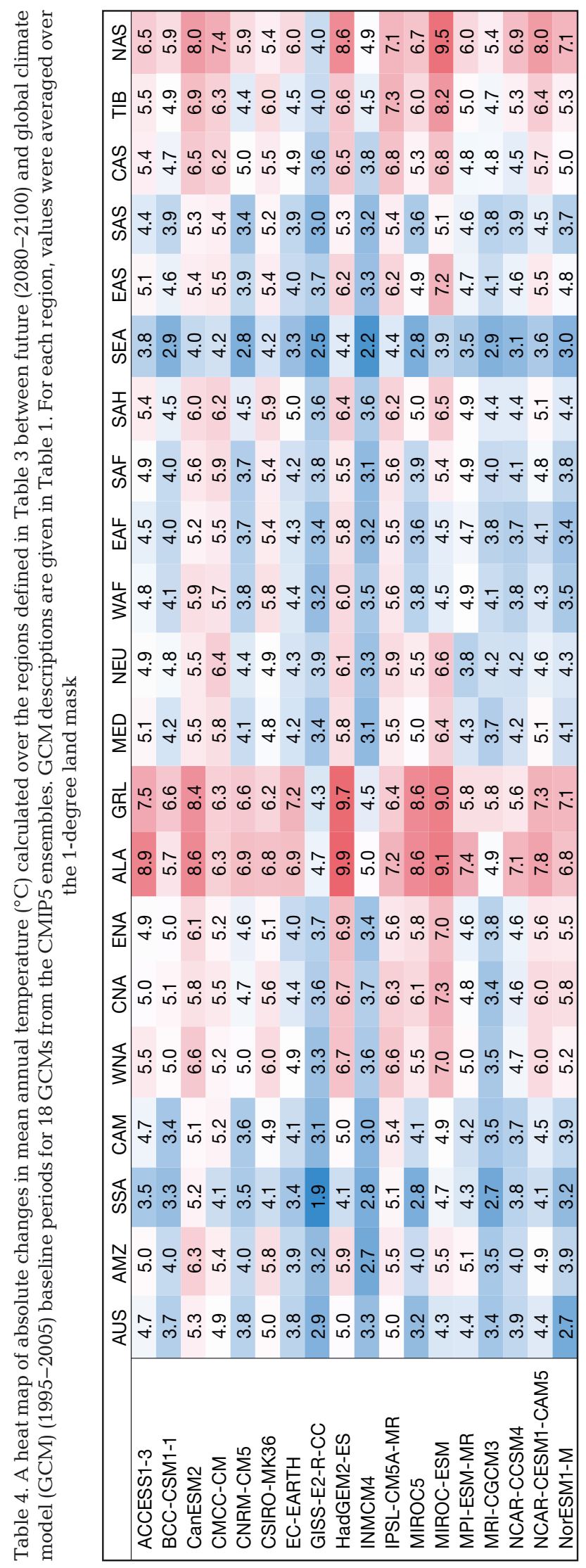




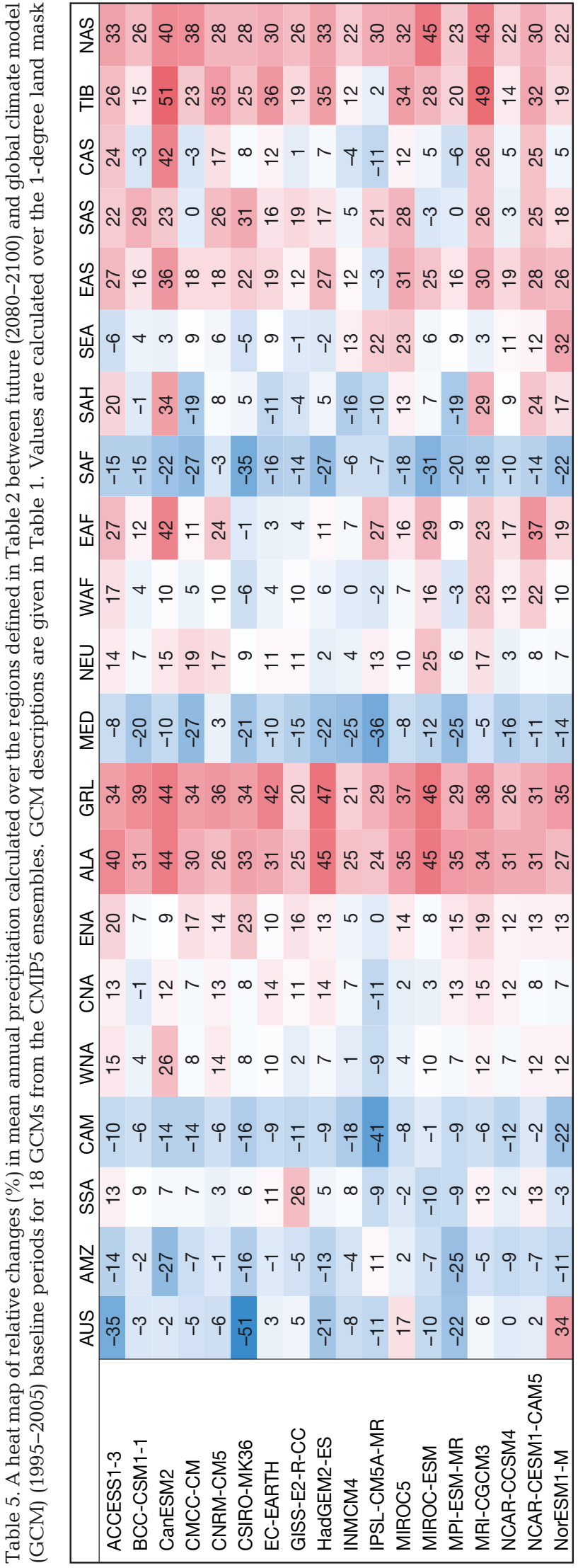

for the impacts of high temperature around flowering and at the beginning of grain filling, the calculation of potential grain number and potential grain weight has been modified in Sirius (Stratonovitch \& Semenov in press). To account for the effect of high temperature on meiosis and fertilisation, the number of grains produced per unit of ear dry mass linearly decreases when, during the $10 \mathrm{~d}$ prior to anthesis, the maximum canopy temperature exceeds a threshold temperature $\mathrm{T}^{\mathrm{N}}$. The potential weight of each grain linearly decreases if the maximum canopy temperature during a period from 5 to $12 \mathrm{~d}$ after anthesis exceeds a threshold temperature $\mathrm{T}^{\mathrm{W}}$. In our simulations, we did not vary parameters affecting grain numbers and grain weight. Instead, we considered future wheat ideotypes to be heat-tolerant (HT) or heat-sensitive (HS) and optimised only 9 remaining cultivar parameters (Table 7). For the HS ideotype, the parameter values for grain number and grain weight reductions were derived from Prasad \& Djanaguiraman (2014), i.e. $\mathrm{T}^{\mathrm{N}}=27^{\circ} \mathrm{C}$ and $\mathrm{T}^{\mathrm{W}}=30^{\circ} \mathrm{C}$. In their experiment, the cultivar 'Chinese spring' was used because of known sensitivity to heat stress at flowering and at the beginning of grain filling (Qin et al. 2008).

\subsection{Wheat ideotype optimisation set-up}

One hundred years of site-specific daily weather were generated by the LARS-WG weather generator at 2 sites, RR and SL, for 2 GCMs, HadGEM2-ES (HadGEM) and GISS-E2-R-CC (GISS), for 2 RCPs, RCP4.5 and RCP8.5, and for 2 future periods, 2050 and 2090 (Semenov \& Stratonovitch 2010). Cultivar parameters of new ideotypes were optimised independently for each climate scenario and each site; ideotypes were considered to be HS or HT. The objective for optimisation was to maximise the $100 \mathrm{yr}$ mean yield. Ideotypes with a coefficient of variation (CV) of yield exceeding $15 \%$ were excluded from optimisation to guarantee high yield stability. During optimisation, we discarded from selection ideotypes for which the 90th percentile of harvest index exceeded 0.64 , which is considered the theoretical maximum for wheat (Foulkes et al. 2011). The stopping rule for optimisation was: (1) no further improvement was possible (the search found a local optimum, or EA-SA [evolutionary algorithm with self-adaptation] prematurely converged); or (2) the 95th percentile of yield (Y95) exceeded a specified threshold of $20 \mathrm{t}$ $\mathrm{ha}^{-1}$. All simulations were assumed to be waterlimited, but no $\mathrm{N}$ limitation was simulated. 

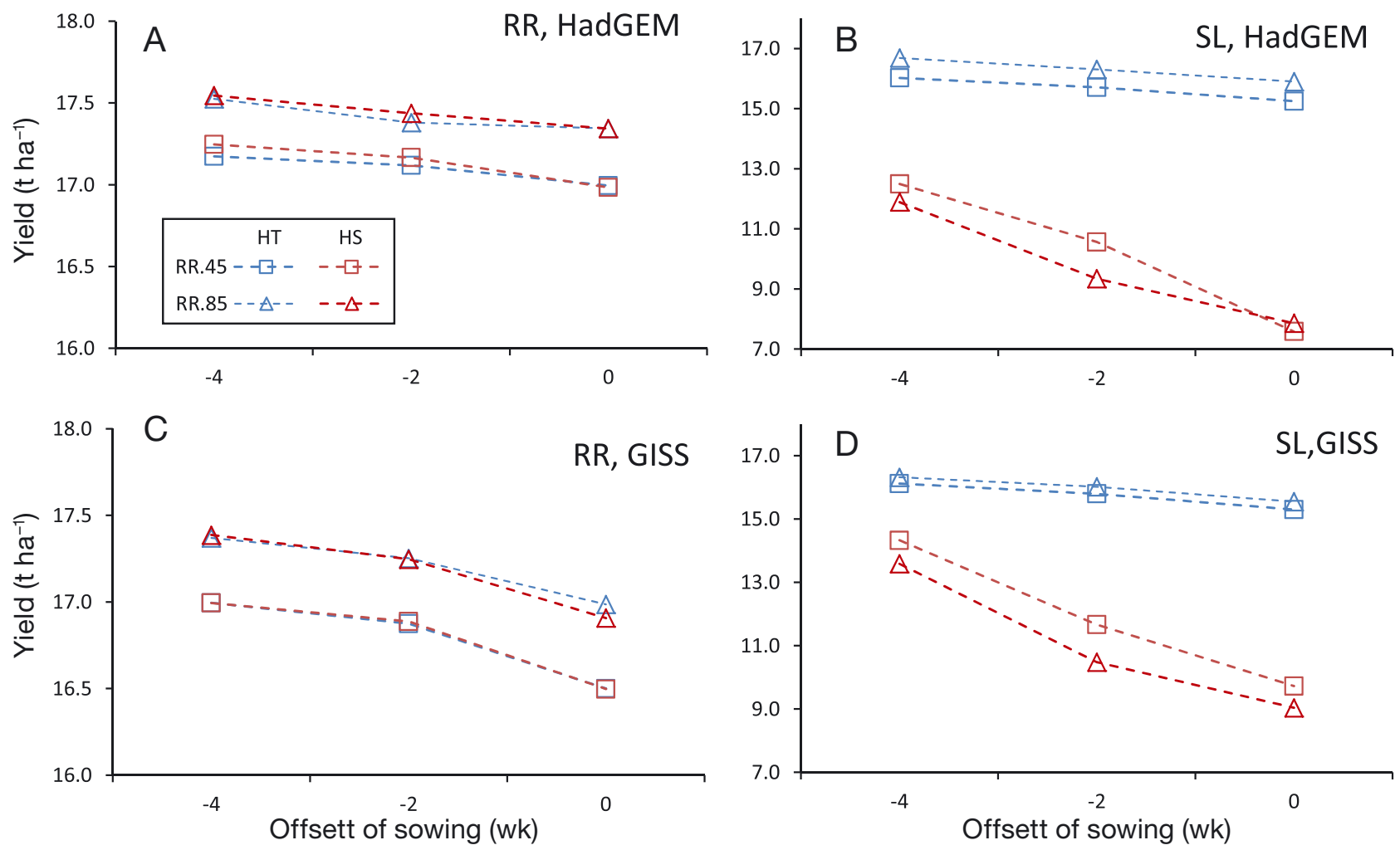

Fig. 2. Response of mean yield to changes in sowing date for ideotypes optimised for 2050 climate scenarios as predicted by 2 global climate models, (A,B) HadGEM and (C,D) GISS, for 2 Representative Concentration Pathways, RCP4.5 and RCP8.5, at 2 sites, $(A, C)$ RR and (B,D) SL. Ideotypes were considered to be heat-tolerant (HT) or heat-sensitive (HS) when optimised for target conditions

respectively, compared with HS ideotypes optimised for hotter HadGEM. The $\left[\mathrm{CO}_{2}\right]$ is predicted to be 11 and $58 \%$ higher for RCP8.5 scenario compared with RCP4.5 for 2050 and 2090, respectively. In Sirius, RUE is proportional to $\left[\mathrm{CO}_{2}\right]$. Therefore, higher yields were simulated for HT ideotypes (and HS ideotypes at RR) for the RCP8.5 scenarios compared with RCP4.5 for both 2050 and 2090, 2-4 and 8-10\%, respectively (Fig. 3B,D). However, at SL, HS ideotypes have slightly higher yields only for RCP8.5 in 2090, and lower yields in 2050, because of nonlinear responses to heat stress around flowering and at the beginning of grain filling.

\subsection{Uncertainty in phenology}

Warmer climate scenarios should bring anthesis forward, on average. For warmer scenarios based on HadGEM, anthesis for HS ideotypes is 5.9 and $17.2 \mathrm{~d}$ earlier compared with scenarios based on GISS for 2050 and 2090, respectively (Fig. 4). The uncertainty of the anthesis date is less for HT ideotypes. For RCP8.5 scenarios, anthesis for both HS and HT ideo- types was about $12 \mathrm{~d}$ earlier compared with RCP4.5 scenarios in 2090. At SL, the difference in anthesis between HS and HT ideotypes could be as high as $3 \mathrm{wk}$, with HS ideotypes developing earlier. However, there were little differences in the grain filling duration (GFD) between HS and HT ideotypes at both sites. In contrast, between sites the difference was large: GFD at RR (70.5 d) is nearly 2 wk longer compared with GFD at SL (56.7 d). This can in part explain consistently higher yields at RR.

\subsection{Stress indexes}

Fig. 5A shows the 95th percentile of the drought stress index (DSI95). The drought stress index is defined as a proportion of the yield lost due to water stress: DSI $=1-\mathrm{Y}_{\mathrm{WL}} / \mathrm{Y}_{\mathrm{P}}$, where $\mathrm{Y}_{\mathrm{WL}}$ and $\mathrm{Y}_{\mathrm{P}}$ are waterlimited and potential grain yields. At RR, DSI95 is approximately half of the values at SL. Simulations for the current cultivars, Mercia and Cartaya, for 2050 climate scenarios showed that their DSI95 was substantially higher compared with optimised ideotypes, i.e. 4.2-fold higher at RR and 2.8-fold at SL 

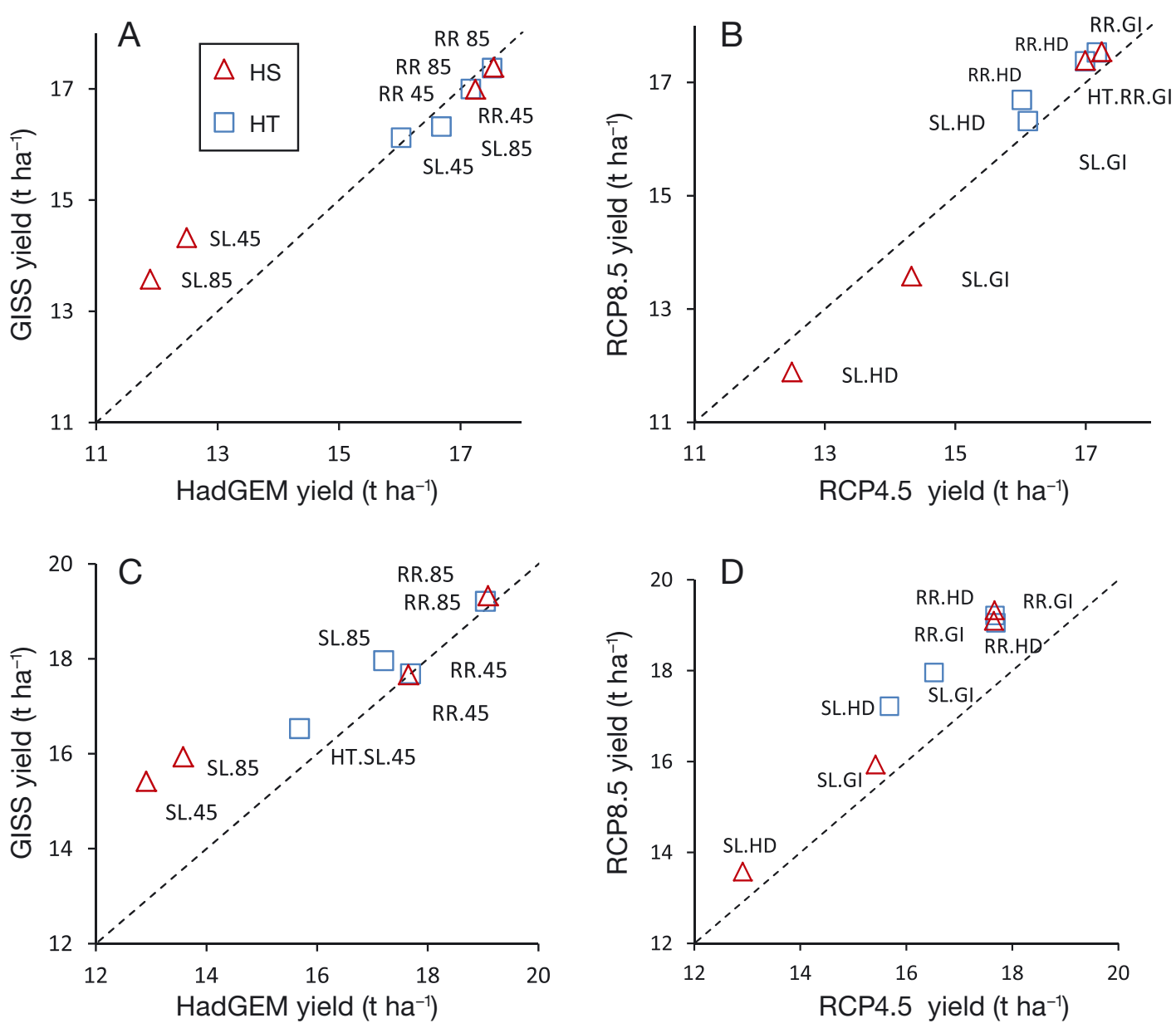

Fig. 3. Mean yields for ideotypes optimised for future (A,B) 2050 and (C,D) 2090 climates at 2 sites, RR and SL: (A,C) HadGEM (HD) vs. GISS (GI); (B,D) RCP4.5 vs. RCP8.5. Ideotypes were considered to be heat-tolerant (HT) or heat-sensitive (HS)

(Semenov et al. 2014). This can be explained by optimal phenology for ideotypes and improvements in responses to water stress (see Fig. 6). Fig. 5B shows the 95th percentile of the heat stress index (HSI95). The heat stress index is defined in a similar way for HS ideotypes as a proportion of the yield lost due to heat stress: $\mathrm{HSI}=1-\mathrm{Y}_{\mathrm{HS}} / \mathrm{Y}_{\mathrm{HT}}$, where $\mathrm{Y}_{\mathrm{HS}}$ is yield of HS ideotype and $\mathrm{Y}_{\mathrm{HT}}$ is yield of the same ideotype if heat tolerance is incorporated. At RR, HSI95 is equal to 0 for all scenarios. At SL, HSI95 varies in the range 0.25-0.45, with lower values for 2090 scenarios (Fig. 5B).

\subsection{Optimal cultivar parameters}

Fig. 6 shows normalised values of 8 cultivar parameters of HS and HT wheat ideotypes which were optimised for 2050 climate scenarios for all combinations of $\mathrm{GCM} \times \mathrm{RCP} \times$ Sites. Normalised values can vary between 0 and 1, corresponding to the minimum and maximum parameter values defined in Table 7 .

At site RR (Fig. 6A), despite high uncertainty in climate scenarios, 5 parameters for both HS and HT ideotypes converged to their optimal values, regardless of which climate scenario was used. Grain fill duration $G$, maximum area of flag leaf $A$ and 'stay green' $S$ reached their maximum values, and response of photosynthesis to water stress Wsa and maximum acceleration of leaf senescence Wss converged to their minimum values. There was no convergence to a single value in parameters related to wheat phenology, phyllochron $P h$ and daylength response $P p$. There are 2 reasons for this. Firstly, because of a difference in temperature increases between different combinations of GCM $\times \mathrm{RCP}$, phenology parameters need to be tuned exactly for each combination of GCM $\times$ RCP to deliver an optimal anthesis date. Secondly, $P h$ and $P p$ both affect development, and even for a single scenario, differ- 

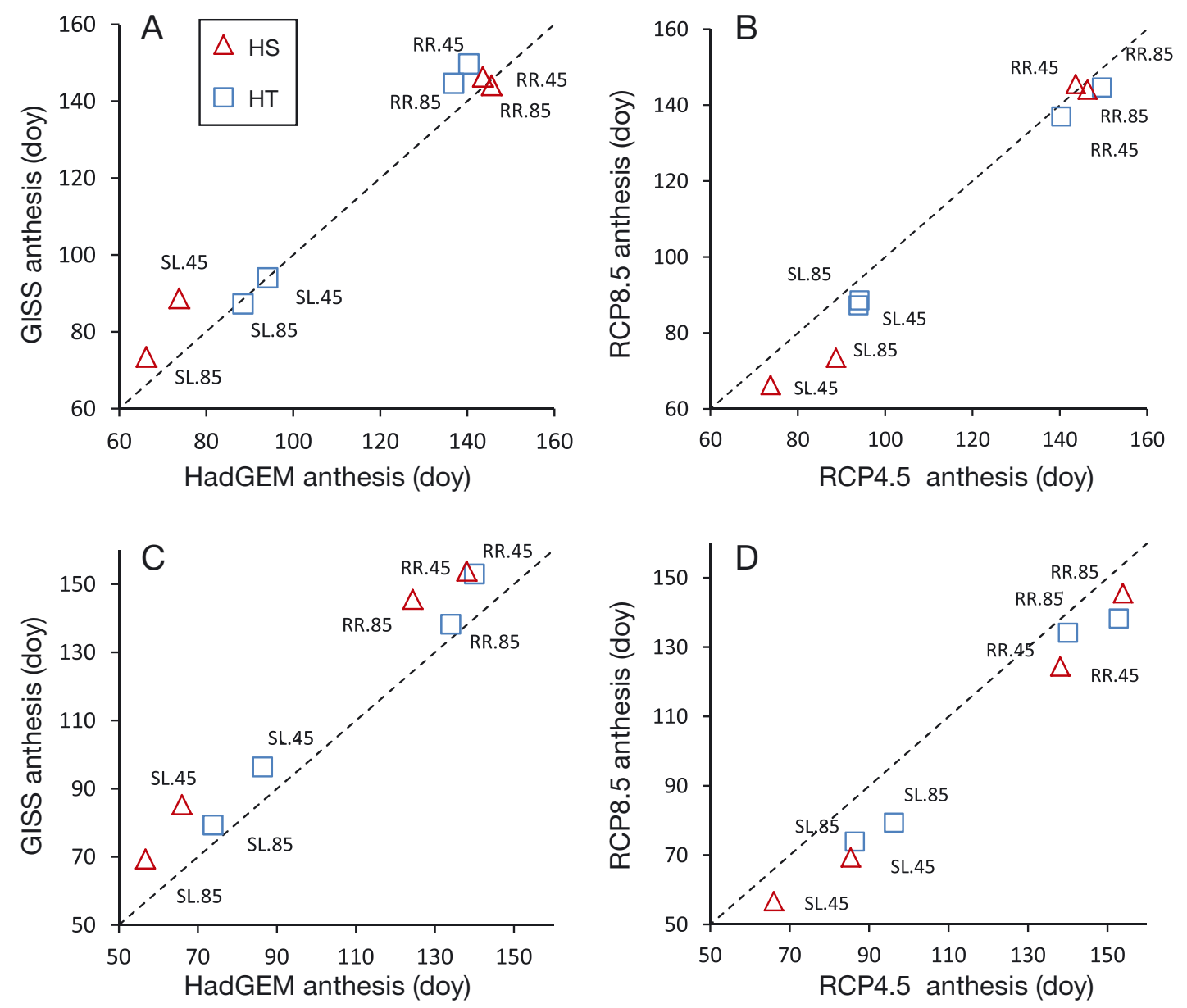

Fig. 4. Mean anthesis date (day of the year, doy) for ideotypes optimised for future (A,B) 2050 and $(\mathrm{C}, \mathrm{D}) 2090$ climates at 2 sites, RR and SL: (A,C) HadGEM vs. GISS; (B,D) RCP4.5 (45) vs. RCP8.5 (85). Ideotypes were considered to be heat-tolerant (HT) or heat-sensitive (HS)
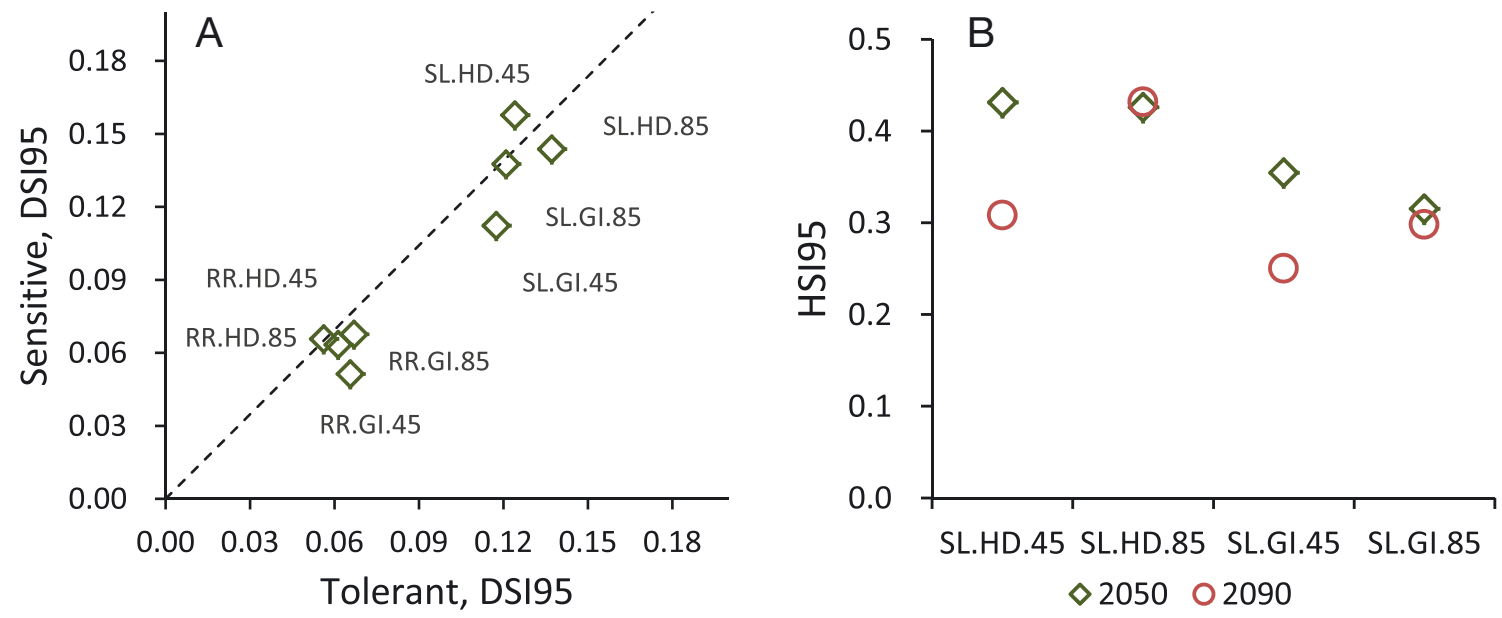

Fig. 5. (A) 95th percentile of the drought stress index (DSI95) of heat-sensitive vs. heat-tolerant ideotypes optimised for 2050 climate scenarios for HadGEM (HD) and GISS (GI) climate models and RCP4.5 (45) and RCP8.5 (85) concentration pathways at sites RR and SL; (B) 95th percentile of the heat stress index (HSI95) of heat-sensitive ideotypes optimised for 2050 and 2090 climate scenarios for HadGEM (HD) and GISS (GI) climate models and RCP4.5 (45) and RCP8.5 (85) concentration pathways at site SL. Ideotypes were optimised independently for all combinations of GCM $\times$ RCP $\times$ Site $\times$ Year 
A

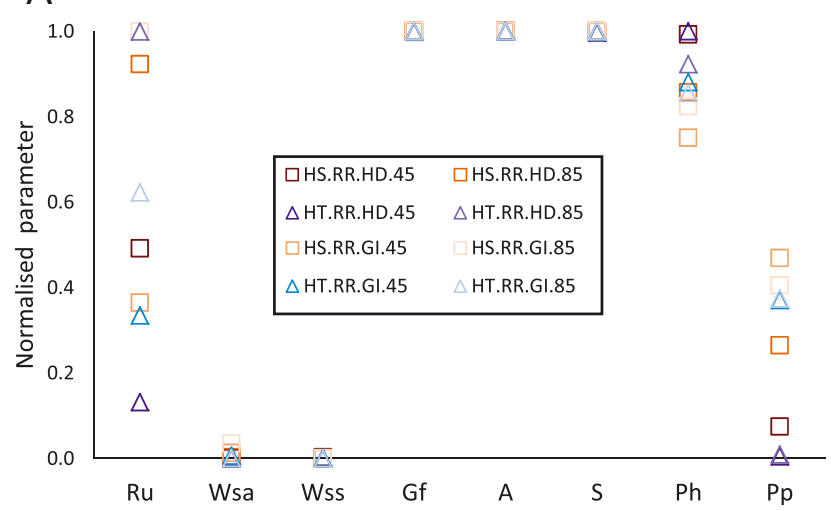

B

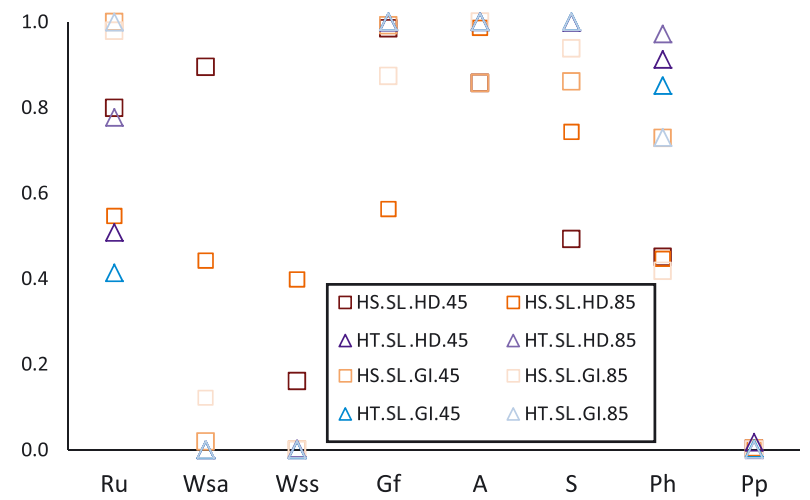

Fig. 6. Normalised values of cultivar parameters (see Table 7 for abbreviations) of heat-tolerant (HT) and heat-sensitive (HS) ideotypes optimised for 2050 climate scenarios for HadGEN (HD) and GISS (GI) climate models and RCP4.5 (45) and RCP8.5 (85) concentration pathways at sites (A) RR and (B) SL. Ideotypes were optimised independently for all combinations of GCM $\times$ $\mathrm{RCP} \times$ Site

ent combinations of $P h$ and $P p$ could deliver optimal anthesis. There was no convergence in water uptake parameter $R u$, which probably means that there is no optimal rate of water uptake at RR.

At site SL (Fig. 6B), convergence of cultivar parameters for HT ideotypes was similar to that at RR. However, HS ideotypes demonstrated different behaviour. It appears that the most important trait to optimise for HS ideotypes at SL was to bring anthesis earlier in the season to avoid the damaging effect of heat stress. For the 2050 HadGEM (RCP8.5) scenario (the hottest), the mean anthesis date for a HS ideotype was more than 3 wk earlier compared with an HT ideotype: 66.3 and 88.5 d, respectively (Fig. 4A). By avoiding heat stress at anthesis, HS ideotypes also avoided drought stress. For the 2050 HadGEM (RCP8.5) scenario, mean DSI for an HS ideotype was half of DSI for an HT ideotype. That could explain the lack of convergence in the drought-tolerance cultivar parameters Wsa and Wss. Although Gf, $A$ and $S$ did not reach their maximum values, most of them were above 0.75 .

One of the emerging messages from our analysis is that wheat phenology must be tailored to specific climate scenarios to achieve maximum yield potentials. Because of uncertainty in future climate projections, optimal phenological parameters for the 2050s cannot be specified at present. A prudent breeding strategy would be to keep sufficient genetic diversity in wheat to control wheat phenology to be able to adapt wheat development to a changing climate.

However, there are some wheat traits which can improve yield potential regardless of the climate scenario selected. One of them is extended duration of grain filling, which results in an increased harvest index. This is only possible if both 'sink' and 'source' capacities are increased. The 'source' capacity can be increased if the plant is able to maintain healthy leaf area until the end of grain filling. In waterlimited environments, improvement in drought tolerance, which delays leaf senescence, could be essential. The 'sink' capacity can be increased if the number of fertile florets at anthesis and, as a result, the number of grains at maturity, increase. The floret survival rate in most wheat cultivars varies in the range $25-40 \%$; so, in principle, there is a large potential for improvement (Gonzalez et al. 2011). Our simulation showed that the lack of heat tolerance in wheat could impose serious limitations on yield potential in Southern Europe (Prasad \& Djanaguiraman 2014). For the 2050 HadGEM (RCP8.5) scenario at SL, the mean yield of a HT ideotype was $40 \%$ higher compared with the yield of a HS ideotype (Fig. 3).

\section{CONCLUDING REMARKS}

We describe integration of climate change projections from the multi-model CMIP5 ensemble with the LARS-WG weather generator, which delivers an attractive option for downscaling of large-scale climate projections from GCMs to local-scale climate scenarios for impact assessments. This work further extended 2 repositories of local-scale climate scenarios, ELPIS for Europe (Semenov et al. 2010) and ELPIS-JP for Japan (Iizumi et al. 2012), with the most up-todate climate projections used in the latest IPCC AR5 (Barros et al. 2014, Edenhofer et al. 2014, Field et al. 
2014). A subset of $18 \mathrm{GCMs}$ from the CMIP5 ensemble and 2 RCPs, i.e. RCP4.5 and RCP8.5, were integrated with LARS-WG. It is important to understand that all combinations of GCM $\times$ RCP should be treated as equally possible, and no probabilities should be attached to impact outcomes based on these climate projections (Stephenson et al. 2012).

CSIs for temperature and precipitation were computed for all $18 \mathrm{GCMs}$ and for 21 regions defined in Giorgi \& Francisco (2000). For computationally demanding impact assessments, where it is not practical to explore all possible combinations of GCM $\times$ $\mathrm{RCP}, \mathrm{CSIs}$ could be used to select a subset of GCMs from the CMIP5 ensemble with contrasting climate sensitivity. This should allow assessment of uncertainty in impacts resulting from the CMIP5 ensemble by conducting fewer simulation experiments. An alternative approach to limit the number of GCMs for an impact study could be to consider the 'reliability' of present-day GCM simulations with respect to observations and select those GCMs which performed better over a region of interest (Yokohata et al. 2013).

We describe in silico design of wheat ideotypes optimised for future climates in Europe, sampling uncertainty in GCMs, emission scenarios, time periods and European locations with contrasting climates. Despite large uncertainty in future climate projections, we were able to identify target traits for wheat improvement which may assist breeding for high-yielding wheat cultivars with increased yield stability.

Acknowledgements. We thank 3 anonymous reviewers for their helpful comments. We acknowledge the World Climate Research Programme's Working Group on Coupled Modelling responsible for CMIP5, and we thank the climate modelling groups for making available their model output. We acknowledge support from an international research project named 'FACCE MACSUR - Modelling European Agriculture with Climate Change for Food Security, a FACCE JPI knowledge hub' and the ADAPTAWHEAT project (grant agreement 289842) under the European Union's Seventh Framework Programme (FP7-KBBE-2011-5). Rothamsted Research receives strategic funding from the Biotechnology and Biological Sciences Research Council of the United Kingdom.

\section{LITERATURE CITED}

Agarwal A, Babel MS, Maskey S (2014) Analysis of future precipitation in the Koshi river basin, Nepal. J Hydrol 513:422-434

Akkaya A, Dokuyucu T, Kara R, Akçura M (2006) Harmonization ratio of post- to pre-anthesis durations by thermal times for durum wheat cultivars in a Mediterranean environment. Eur J Agron 24:404-408
Alghabari F, Lukac M, Jones HE, Gooding MJ (2014) Effect of Rht alleles on the tolerance of wheat grain set to high temperature and drought stress during booting and anthesis. J Agron Crop Sci 200:36-45

> Asseng S, Ritchie JT, Smucker AJM, Robertson MJ (1998) Root growth and water uptake during water deficit and recovering in wheat. Plant Soil 201:265-273

Barros VR, Field CB, Dokken DJ, Mastrandrea MD and others (eds) (2014) Climate change 2014: impacts, adaptation, and vulnerability. Part B. Regional aspects. Contribution of Working Group II to the Fifth Assessment Report of the Intergovernmental Panel on Climate Change. Cambridge University Press, Cambridge

Barrow EM, Semenov MA (1995) Climate change scenarios with high spatial and temporal resolution for agricultural applications. Forestry 68:349-360

Bellucci A, Gualdi S, Masina S, Storto A and others (2013) Decadal climate predictions with a coupled OAGCM initialized with oceanic reanalyses. Clim Dyn 40:1483-1497

Bentsen M, Bethke I, Debernard JB, Iversen T and others (2013) The Norwegian Earth System Model, NorESM1M. Part 1. Ddescription and basic evaluation of the physical climate. Geosci Model Dev 6:687-720

Brovkin V, Boysen L, Raddatz T, Gayler V, Loew A, Claussen M (2013) Evaluation of vegetation cover and land-surface albedo in MPI-ESM CMIP5 simulations. J Adv Model Earth Syst 5:48-57

> Calanca P, Semenov MA (2013) Local-scale climate scenarios for impact studies and risk assessments: integration of early 21st century ENSEMBLES projections into the ELPIS database. Theor Appl Climatol 113:445-455

> Chandler MA, Sohl LE, Jonas JA, Dowsett HJ, Kelley M (2013) Simulations of the mid-Pliocene Warm Period using two versions of the NASA/GISS ModelE2-R Coupled Model. Geosci Model Dev 6:517-531

Charmet G, Robert N, Branlard G, Linossier L, Martre P, Triboï E (2005) Genetic analysis of dry matter and nitrogen accumulation and protein composition in wheat kernels. Theor Appl Genet 111:540-550

> Christensen JH, Boberg F, Christensen OB, Lucas-Picher P (2008) On the need for bias correction of regional climate change projections of temperature and precipitation. Geophys Res Lett 35:L20709, doi:10.1029/2008GL035694

Chylek P, Li J, Dubey MK, Wang M, Lesins G (2011) Observed and model simulated 20th century Arctic temperature variability: Canadian Earth System Model CanESM2. Atmos Chem Phys Discuss 11:22893-22907

Collier M, Uhe P (2012) CMIP5 datasets from the ACCESS1.0 and ACCESS1.3 coupled climate models. CAWCR Tech Rep 059. Centre for Australian Weather and Climate Research, Aspendale

Collier M, Jeffrey S, Rotstayn L (2011) The latest Australian CMIP climate model submission. Bull Aust Meteorol Oceanogr Soc 24:104-108

> Collins WJ, Bellouin N, Doutriaux-Boucher M, Gedney N and others (2011) Development and evaluation of an Earth-System model - HadGEM2. Geosci Model Dev 4: 1051-1075

Donald CM (1968) The breeding of crop ideotypes. Euphytica 17:385-403

> Dufresne JL, Foujols MA, Denvil S, Caubel A and others (2013) Climate change projections using the IPSL-CM5 Earth System Model: from CMIP3 to CMIP5. Clim Dyn 40:2123-2165

Edenhofer O, Pichs-Madruga R, Sokona Y, Farahani E and 
others (eds) (2014) Climate change 2014: mitigation of climate change. Contribution of Working Group III to the Fifth Assessment Report of the Intergovernmental Panel on Climate Change. Cambridge University Press, Cambridge

Evans LT, Fischer RA (1999) Yield potential: its definition, measurement and significance. Crop Sci 39:1544-1551

FAO (2009) How to feed the world in 2050. High-level experts forum. FAO, Rome

Ferris R, Ellis RH, Wheeler TR, Hadley P (1998) Effect of high temperature stress at anthesis on grain yield and biomass of field-grown crops of wheat. Ann Bot 82: 631-639

Field CB, Barros VR, Dokken DJ, Mach KJ and others (eds) (2014) Climate change 2014: impacts, adaptation, and vulnerability. Part A. Global and sectoral aspects. Contribution of Working Group II to the Fifth Assessment Report of the Intergovernmental Panel on Climate Change. Cambridge University Press, Cambridge

> Fischer EM, Beyerle U, Knutti R (2013) Robust spatially aggregated projections of climate extremes. Nat Clim Change 3:1033-1038

> Fischer RA, Rees D, Sayre KD, Lu ZM, Condon AG, Saavedra AL (1998) Wheat yield progress associated with higher stomatal conductance and photosynthetic rate, and cooler canopies. Crop Sci 38:1467-1475

> Foulkes MJ, Slafer GA, Davies WJ, Berry PM and others (2011) Raising yield potential of wheat. III. Optimizing partitioning to grain while maintaining lodging resistance. J Exp Bot 62:469-486

> Giorgi F, Francisco R (2000) Uncertainties in regional climate change prediction: a regional analysis of ensemble simulations with the HADCM2 coupled AOGCM. Clim Dyn 16:169-182

Gonzalez FG, Miralles DJ, Slafer GA (2011) Wheat floret survival as related to pre-anthesis spike growth. J Exp Bot 62:4889-4901

> Grant RF, Kimball BA, Conley MM, White JW, Wall GW, Ottman MJ (2011) Controlled warming effects on wheat growth and yield: field measurements and modeling. Agron J 103:1742-1754

> Hammer G, Cooper M, Tardieu F, Welch S and others (2006) Models for navigating biological complexity in breeding improved crop plants. Trends Plant Sci 11:587-593

> Hassan Z, Shamsudin S, Harun S (2014) Application of SDSM and LARS-WG for simulating and downscaling of rainfall and temperature. Theor Appl Climatol 116: 243-257

Hawker JS, Jenner CF (1993) High temperature affects the activity of enzymes in the committed pathway of starch synthesis in developing wheat endosperm. Aust J Plant Physiol 20:197-209

> Hazeleger W, Wang X, Severijns C, Stefanescu S and others (2012) EC-Earth V2.2: description and validation of a new seamless earth system prediction model. Clim Dyn 39:2611-2629

Iizumi T, Semenov MA, Nishimori M, Ishigooka Y, Kuwagata T (2012) ELPIS-JP: a dataset of local-scale daily climate change scenarios for Japan. Philos Trans R Soc A 370:1121-1139

> Ishag HM, Mohamed BA, Ishag KHM (1998) Leaf development of spring wheat cultivars in an irrigated heatstressed environment. Field Crops Res 58:167-175

- Iversen T, Bentsen M, Bethke I, Debernard JB and others (2013) The Norwegian Earth System Model, NorESM1-
M. Part 2. Climate response and scenario projections. Geosci Model Dev 6:389-415

Jahn A, Holland MM (2013) Implications of Arctic sea ice changes for North Atlantic deep convection and the meridional overturning circulation in CCSM4-CMIP5 simulations. Geophys Res Lett 40:1206-1211

> Jamieson PD, Semenov MA (2000) Modelling nitrogen uptake and redistribution in wheat. Field Crops Res 68: 21-29

Jamieson PD, Semenov MA, Brooking IR, Francis GS (1998) Sirius: a mechanistic model of wheat response to environmental variation. Eur J Agron 8:161-179

> Jones CD, Hughes JK, Bellouin N, Hardiman SC and others (2011) The HadGEM2-ES implementation of CMIP5 centennial simulations. Geosci Model Dev 4:543-570

Knutti R, Sedlacek J (2013) Robustness and uncertainties in the new CMIP5 climate model projections. Nat Clim Change 3:369-373

Kosner J, Zurkova D (1996) Photoperiodic response and its relation to earliness in wheat. Euphytica 89:59-64

Kysely J, Dubrovsky M (2005) Simulation of extreme temperature events by a stochastic weather generator: effects of interdiurnal and interannual variability reproduction. Int J Climatol 25:251-269

Kysely J, Gaal L, Picek J, Schindler M (2013) Return periods of the August 2010 heavy precipitation in northern Bohemia (Czech Republic) in the present climate and under climate change. J Water Clim Change 4:265-286

Lawless C, Semenov MA, Jamieson PD (2005) A wheat canopy model linking leaf area and phenology. Eur J Agron 22:19-32

Luo Q, Bange M, Clancy L (2014) Cotton crop phenology in a new temperature regime. Ecol Model 285:22-29

Manschadi AM, Christopher J, Devoil P, Hammer GL (2006) The role of root architectural traits in adaptation of wheat to water-limited environments. Funct Plant Biol 33: 823-837

Martin GM, Bellouin N, Collins WJ, Culverwell ID and others (2011) The HadGEM2 family of Met Office Unified Model climate configurations. Geosci Model Dev 4: 723-757

Meehl GA, Washington WM, Arblaster JM, Hu A and others (2013) Climate change projections in CESM1(CAM5) compared to CCSM4. J Clim 26:6287-6308

> Meinshausen M, Raper SCB, Wigley TML (2011) Emulating coupled atmosphere-ocean and carbon cycle models with a simpler model, MAGICC6. Part 1. Model description and calibration. Atmos Chem Phys 11:1417-1456

Mochizuki T, Chikamoto Y, Kimoto M, Ishii M and others (2012) Decadal prediction using a recent series of MIROC global climate models. J Meteorol Soc Jpn 90A: 373-383

> Moss RH, Edmonds JA, Hibbard KA, Manning MR and others (2010) The next generation of scenarios for climate change research and assessment. Nature 463:747-756

> Mossad MG, Ortiz-Ferrara G, Mahalakshmi V, Fischer RA (1995) Phyllochron response to vernalization and photoperiod in spring wheat. Crop Sci 35:168-171

Nakicenovic N, Swart R (eds) (2000) Emissions scenarios 2000. Special report of the Intergovernmental Panel on Climate Change. Cambridge University Press, Cambridge

Parry ML, Canziani OF, Palutikof JP, van der Linden PJ, Hanson CE (eds) (2007) Climate change 2007: impacts, adaptation and vulnerability. Contribution of Working 
Group II to the Fourth Assessment Report of the Intergovernmental Panel on Climate Change. Cambridge University Press, Cambridge

Parry MAJ, Reynolds M, Salvucci ME, Raines C and others (2011) Raising yield potential of wheat. II. Increasing photosynthetic capacity and efficiency. J Exp Bot 62:453-467

Persson T, Hoglind M (2014) Impact of climate change on harvest security and biomass yield of two timothy ley harvesting systems in Norway. J Agric Sci 152:205-216

> Porter JR, Semenov MA (2005) Crop responses to climatic variation. Philos Trans R Soc B 360:2021-2035

> Prasad PV, Djanaguiraman M (2014) Response of floret fertility and individual grain weight of wheat to high temperature stress: sensitive stages and thresholds for temperature and duration. Funct Plant Biol 41:1261-1269

> Qian B, Gameda S, Hayhoe H, De Jong R, Bootsma A (2004) Comparison of LARS-WG and AAFC-WG stochastic weather generators for diverse Canadian climates. Clim Res 26:175-191

Qian B, Gameda S, Hayhoe H (2008) Performance of stochastic weather generators LARS-WG and AAFC-WG for reproducing daily extremes of diverse Canadian climates. Clim Res 37:17-33

Qin D, Wu H, Peng H, Yao Y and others (2008) Heat stressresponsive transcriptome analysis in heat susceptible and tolerant wheat (Triticum aestivum L.) by using Wheat Genome Array. BMC Genomics 9:432, doi:10. 1186/1471-2164-9-432

Racsko P, Szeidl L, Semenov M (1991) A serial approach to local stochastic weather models. Ecol Model 57:27-41

Riahi K, Gruebler A, Nakicenovic N (2007) Scenarios of long-term socio-economic and environmental development under climate stabilization. Technol Forecast Soc Change 74:887-935

Richards RA (1991) Crop improvement for temperate Australia: future opportunities. Field Crops Res 26:141-169

Richardson CW (1981) Stochastic simulation of daily precipitation, temperature, and solar radiation. Water Resour Res 17:182-190

Robert N, Hennequet C, Bérard P (2001) Dry matter and nitrogen accumulation in wheat kernel: genetic variation in rate and duration of grain filling. J Genet Breed 55: 297-305

Schmidt H, Rast S, Bunzel F, Esch M and others (2013) Response of the middle atmosphere to anthropogenic and natural forcings in the CMIP5 simulations with the Max Planck Institute Earth system model. J Adv Model Earth Syst 5:98-116

Semenov MA (2007) Development of high-resolution UKCIP02-based climate change scenarios in the UK. Agric For Meteorol 144:127-138

Semenov MA (2008) Simulation of extreme weather events by a stochastic weather generator. Clim Res 35:203-212

Semenov MA, Barrow EM (1997) Use of a stochastic weather generator in the development of climate change scenarios. Clim Change 35:397-414

Semenov MA, Halford NG (2009) Identifying target traits and molecular mechanisms for wheat breeding under a changing climate. J Exp Bot 60:2791-2804

Semenov MA, Shewry PR (2011) Modelling predicts that heat stress, not drought, will increase vulnerability of wheat in Europe. Sci Rep 1:66

Semenov MA, Stratonovitch P (2010) Use of multi-model ensembles from global climate models for assessment of climate change impacts. Clim Res 41:1-14
Semenov MA, Brooks RJ, Barrow EM, Richardson CW (1998) Comparison of the WGEN and LARS-WG stochastic weather generators in diverse climates. Clim Res 10: 95-107

Semenov MA, Donatelli M, Stratonovitch P, Chatzidaki E, Baruth B (2010) ELPIS: a dataset of local-scale daily climate scenarios for Europe. Clim Res 44:3-15

Semenov MA, Pilkington-Bennett S, Calanca P (2013) Validation of ELPIS 1980-2010 baseline scenarios using the observed European Climate Assessment data set. Clim Res 57:1-9

> Semenov MA, Stratonovitch P, Alghabari F, Gooding MJ (2014) Adapting wheat in Europe for climate change. J Cereal Sci 59:245-256

> Shearman VJ, Sylvester-Bradley R, Scott RK, Foulkes MJ (2005) Physiological processes associated with wheat yield progress in the UK. Crop Sci 45:175-185

Smith SJ, Wigley TML (2006) Multi-gas forcing stabilization with Minicam. Energy J 27:373-391

Solomon S, Qin D, Manning M, Marquis M and others (eds) (2007) Climate change 2007: the physical science basis. Contribution of Working Group I to the Fourth Assessment Report of the Intergovermental Panel on Climate Change. Cambridge University Press, New York, NY

Stephenson DB, Collins M, Rougier JC, Chandler RE (2012) Statistical problems in the probabilistic prediction of climate change. Environmetrics 23:364-372

Stocker TF, Qin D, Plattner GK, Tignor M and others (eds) (2013) Climate change 2013: the physical science basis. Contribution of Working Group I to the Fifth Assessment Report of the Intergovernmental Panel on Climate Change. Cambridge University Press, Cambridge

> Storkey J, Stratonovitch P, Chapman DS, Vidotto F, Semenov MA (2014) A process-based approach to predicting the effect of climate change on the distribution of an invasive allergenic plant in Europe. PLoS ONE 9:e88156

> Stratonovitch P, Semenov MA (2010) Calibration of a crop simulation model using an evolutionary algorithm with self-adaptation. Procedia Soc Behav Sci 2:7749-7750

Stratonovitch P, Semenov MA (in press) Heat tolerance around flowering in wheat identified as a key trait for increased yield potential in Europe under climate change. J Exp Bot, doi:10.1093/jxb/erv070

Tambussi EA, Bort J, Araus JL (2007) Water use efficiency in C3 cereals under Mediterranean conditions: a review of physiological aspects. Ann Appl Biol 150:307-321

Tardieu F, Tuberosa R (2010) Dissection and modelling of abiotic stress tolerance in plants. Curr Opin Plant Biol 13: 206-212

Tatebe H, Ishii M, Mochizuki T, Chikamoto Y and others (2012) The initialization of the MIROC climate models with hydrographic data assimilation for decadal prediction. J Meteorol Soc Jpn 90A:275-294

Taylor KE, Stouffer RJ, Meehl GA (2012) An overview of CMIP5 and the experiment design. Bull Am Meteorol Soc 93:485-498

Triboi E, Triboi-Blondel AM (2002) Productivity and grain or seed composition: a new approach to an old problem invited paper. Eur J Agron 16:163-186

Tsujino H, Hirabara M, Nakano H, Yasuda T, Motoi T, Yamanaka G (2011) Simulating present climate of the global ocean-ice system using the Meteorological Research Institute Community Ocean Model (MRI.COM): simulation characteristics and variability in the Pacific sector. J Oceanogr 67:449-479 
Vanuytrecht E, Raes D, Willems P, Geerts S (2012) Quantifying field-scale effects of elevated carbon dioxide concentration on crops. Clim Res 54:35-47

Vanuytrecht E, Raes D, Willems P, Semenov MA (2014) Comparing climate change impacts on cereals based on CMIP3 and EU-ENSEMBLES climate scenarios. Agric For Meteorol 195-196:12-23

> Voldoire A, Sanchez-Gomez E, Salas y Melia D, Decharme B and others (2013) The CNRM-CM5.1 global climate model: description and basic evaluation. Clim Dyn 40:2091-2121

Volodin EM, Diansky NA, Gusev AV (2013) Simulation and prediction of climate changes in the 19th to 21st centuries with the Institute of Numerical Mathematics, Russian Academy of Sciences, model of the Earth's climate system. Izv Atmos Ocean Phys 49:347-366

Wang C, Zhang L, Lee SK, Wu L, Mechoso CR (2014) A global perspective on CMIP5 climate model biases. Nat Clim Change 4:201-205

Watanabe S, Hajima T, Sudo K, Nagashima T and others (2011) MIROC-ESM 2010: model description and basic results of CMIP5-20c3m experiments. Geosci Model Dev 4:845-872

- Wheeler TR, Batts GR, Ellis RH, Hadley P, Morison JIL (1996) Growth and yield of winter wheat (Triticum aestivum) crops in response to $\mathrm{CO}_{2}$ and temperature. J Agric Sci 127:37-48

Wilby RL, Wigley TML, Conway D, Jones PD, Hewiston BC, Main J, Wilks DS (1998) Statistical downscaling of general circulation model output: a comparison of methods.

Submitted: October 29, 2014; Accepted: March 12, 2015
Water Resour Res 34:2995-3008

Wilby RL, Troni J, Biot Y, Tedd L, Hewitson BC, Smith DM, Sutton RT (2009) A review of climate risk information for adaptation and development planning. Int J Climatol 29: 1193-1215

Wilks DS (1992) Adapting stochastic weather generation algorithms for climate changes studies. Clim Change 22: 67-84

Wilks DS (2012) Stochastic weather generators for climatechange downscaling. II. Multivariable and spatially coherent multisite downscaling. Wiley Interdiscip Rev Clim Change 3:267-278

Wise M, Calvin K, Thomson A, Clarke L and others (2009) Implications of limiting $\mathrm{CO}_{2}$ concentrations for land use and energy. Science 324:1183-1186

Yokohata T, Annan JD, Collins M, Jackson CS and others (2013) Reliability and importance of structural diversity of climate model ensembles. Clim Dyn 41:2745-2763

Yurova AY, Volodin EM (2011) Coupled simulation of climate and vegetation dynamics. Izv Atmos Ocean Phys 47:531-539

> Zhang L, Wu T, Xin X, Dong M, Wang Z (2012) Projections of annual mean air temperature and precipitation over the globe and in China during the 21st century by the BCC Climate System Model BCC_CSM1.0. Acta Meteorol Sin 26:362-375

Zhu XG, Long SP, Ort DR (2010) Improving photosynthetic efficiency for greater yield. Annu Rev Plant Biol 61: 235-261

Proofs received from author(s): June 11, 2015 